\title{
製品画像の例示による検査アルゴリズムの生成システム
}

\author{
谷. 崎 直 昭* ・岡 村 哲 也*・村上 亨*
}

\section{A Generation System for Inspection Algorithm Based on Sample Products' Images}

\author{
Naoaki Tanizaki*, Tetsuya OKamura* and Tohru Murakami*
}

\begin{abstract}
The inspection systems with image processing equipments have increased in number in recent years. But, it takes not only a lot of time and money but also the assistance of experts to design a new inspection algorithm. So, generalization, which means applying the same inspection system to the other products or defects, is one of the most difficult problem exept the mechanical problems.

In order to solve this problem, we have developed a support system to build up inspection systems. This system generates some candidates of the inspection algorithm through the interaction with the operator and displays the result to the display.
\end{abstract}

The followings are the key points of this paper.

(1) We have developed the new algorithm generation system which needs only the simple operation of the operator. So, it is not necesary for the operator to know enough image processing.

(2) The evaluation method of the inspection algorithm is proposed. It is calculated from the statistical deviation of the products' quality and the operator's inspection strategy.

(3) The algorithm generation method based on the evaluation value and the processing time is proposed.

Key Words : image processing, inspection system, support system, human interface, algorithm generation

\section{1. まえがき}

近年，製品検査の分野では，画像処理を用いた種々の 検査装置が商品化されているが, 限定された範囲での導 入にとどまっているのが現状である。この理由として， 汎用化,つまり, 1 台の検査装置で種々の欠陥を検出でき る能力をもたせることが,むずかしいことが挙げられる. 汎用化を実現する一つの手段として, 基準画像とのパ ターンマッチング方式による検査がある ${ }^{11}$.これは, 適用 範囲の広い沉用モジュールを用意する方向であるが，こ のような相対的な比較方式では, 何を基準とするかに よって検査結果が左右されたり,判定のしきい值決定がむ ずかしいなどの問題があるため, 比較的容易な検査に用 いられることが多い.

\footnotetext{
$\dagger$ 第 30 回計測自動制御学会学術講演会で発表 $(1991 \cdot 7)$

* 住友重機械工業(株) システム技術研究所 田無市谷戸町 2-4-15

* Systems Engineering Laboratory, Sumitomo Heavy Industries, Ltd., Tanashi (Received December 4, 1991)

(Revised May. 21, 1992)
}

ほかの方法として，画像処理アルゴリズムの作成にお いて，人間の試行錯誤過程を支援することにより汎用化 を図る試みがこれまでに数多く行われている。これには， 画像処理手法に関する知識を基にユーザに対する問い合 わせを行いながら画像処理アルゴリズムを作成するも の ${ }^{2)}$, サンプル画像をシステムに入力することによって 目的の領域抽出を行うもの

しかし, 製品検査では, 最終的な検査方法, 検査グレー ドの決定が生産現場で決定されることが多く, 従来の装 置のように専門の画像処理技術者を必要とするもので は, 検査要求に対する柔軟な対応が難しく, 結果として 検査の自動化が妨げられる一因となっていた。

本研究の目的は，これらの問題を解決し，オペレー夕 との簡単な対話により種々の対象の検査アルゴリズムを 自動的に生成するシステムを構築することにある．本論 文では，射出成形機によって生産される電子部品の一つ であるコネクタの外観検查を対象とし, 検査アルゴリズ ムの半自動生成システムを試作し，良好な結果を得たの で報告する4) 6).

2 章ではまず, 検査アルゴリズムの半自動生成戦略と 
検査アルゴリズムの構造について述べる，3 章では，製 品サンプルをもとに製品品質の統計的分布を考慮した検 查アルゴリズムの評価值算出法について述べる，4 章で は，検査アルゴリズムの探索法について述べる，最後に 5 章で, 実際の成形品について, 検查アルゴリズムの生 成を行った結果を示し，本システムの有効性，今回提案 する検査アルゴリズムの評価法および探索法についての 評価, 考察を行う.

\section{2. 半自動生成戦略と検査アルゴリズムの構造化}

一般には，画像処理を用いて製品検查システムを構成 する場合, 欠陥の画像上の特徵を事前に知り，その特徵 を抽出する検査アルゴリズム, すなわち久陥の認識アル ゴリズムを開発することが多い. 本論文で述べる検査ア ルゴリズム生成の基本的な考え方は，これとは違い，あ らかじめ検查者が良品および不良品として判別したいく つかのサンプル画像に対し, 良品と不良品の画像間に存 在する明暗パターンの差を, 最も良く識別できる検査ア ルゴリズムを，あらかじめ用意した検査アルゴリズムの 中から発見することである，この方式によれば，複数の 製品サンプル画像を用いるので，検査アルゴリズムの開 発段階において統計的な品質のばらつきを考慮でき, 信 頼性の高い検查アルゴリズムを得ることができる，した がって本システムは, 本質的にオペレータとの対話に基 づく人間との協調システムである.オペレータが行う操 作内容と, システムが自動的に行う処理内容を Fig. 1 に 示す.

Operator

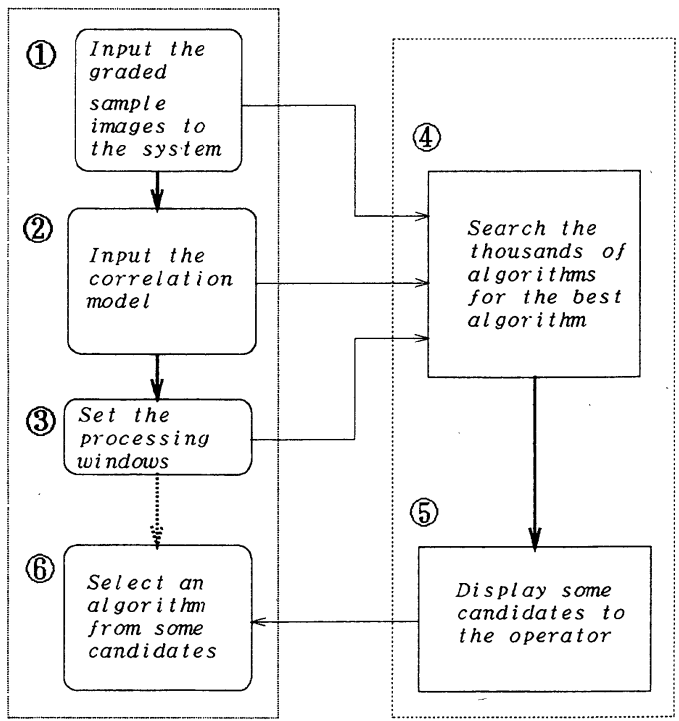

Fig. 1 The operation flow of proposed system
（1）オペレータはまず，目視によって製品サンプル を良品から不良品までいくつかのグレードに分類する. 分類の基準は, 一つの欠宿の特徵, たとえばある場所の 欠けの量であり，各グレードごとに十数個程度のサンプ ルを用意し，グレード值と画像をシステムに入力する。

（2）つぎに，各製品グレードと，検査アルゴリズム が出力するグレード值 (特徴量) との関係を, 相関モデル としてオペレータが入力する.この相関モデルの形状は, 各グレードをどのように良品, 不良品に振り分けるかと いうオペレータの判断により決定し入力する。これにつ いては，3章で詳しく述べる。

（3）オペレー夕は最後に，（1）で注目した欠陷の特 徵が抽出しやすいように検査ウィンドウを決め, これを 画像上に設定する。

（4）以上の入力の後，システムは，あらかじめ組合 せを木として表現した検査アルゴリズムの中から，3 章 の評価法と 4 章の探索法を用い, 相関モデルに合った検 查アルゴリズムの探索を行う。

（5）探索が終了すると，システムは各アルゴリズム の評価值に従い, いくつかの検査アルゴリズムの候補を グラフと表でオペレータに提示する.

（6）最適な検査アルゴリズムは，システムが提示し た候補の中から，オペレータが，良品と不良品の分離性 の良いものを直感的に選択する.

以上のようなオペレータとシステムの対話は，生産技 術者の観点から, 必要な情報のみがグラフィカルなヒュー マンインターフェースを介して行われるため, 画像処 理に対して特別な知識をもたないオペレータにも容易に 操作できる対話環境を提供している，さて，このような システムを構成するために，ここではまず，検査アルゴ リズムの構造を Fig. 2 に示すようなパイプライン型の 処理課程として構造化した. 画像処理過程の構造につい ては，文献 7)，8）に示されるようにいくつか考えられる が，コネクタの検査においては，欠陷発生場所がほぼ特 定できるため，パイプライン型のみでも実用可能な検査 アルゴリズムを構成できると考えられる6. 同図に示す ように検査アルゴリズムは，処理の流れに従って三つの ブロックに分けることができる，第 1 ブロックでは，入 力画像上のウィンドウ領域に対して, 様々な画像演算子 を直列に組み合わせて画像変換を行うことを示す．第 2 ブロックでは, その結果画像に対して, 特徴抽出子を用 いて一つの画像特徵量を抽出することを示す. 最後に, 第 3 ブロックでは, 抽出された特徵量とそれに対するし きい值とから，良否の判定を行うことを示す，以後，第 1 ブロックを画像処理アルゴリズム，第 1 第 2 ブロック を合わせて検査アルゴリズム，第 3 ブロックを検査と呼 


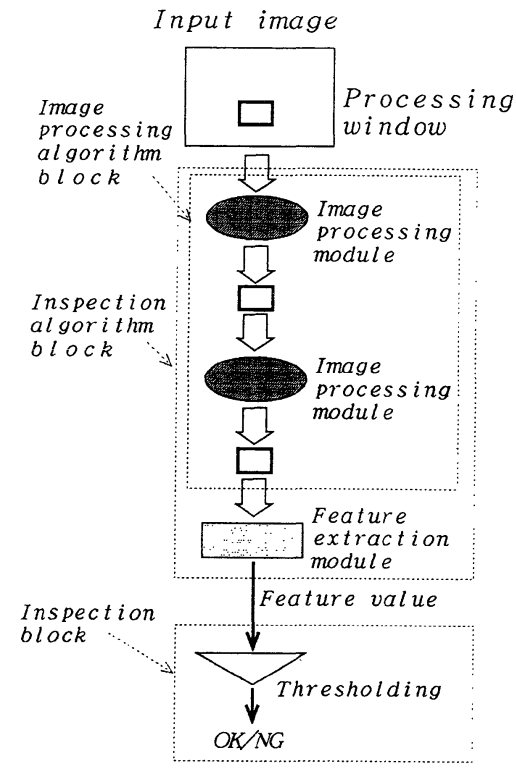

Fig. 2 A pipe-line model of inspection algorithm

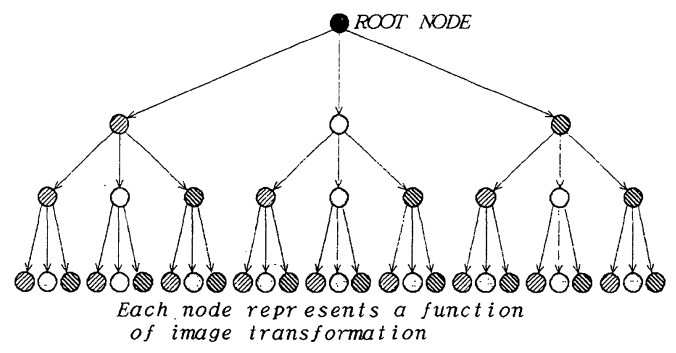

Fig. 3 A tree representation of the algorithm combination

ぶ. 本システムでは，このうち，検査アルゴリズムの生 成支援を行う。この画像処理アルゴリズムは，あらかじ め用意した画像処理演算子の組合せとして求められる が，その可能な組合せは Fig. 3 に示すように，木として 表現できる，同図で，各ノードは画像処理演算子を表わ し，ルートノードからそのノードに至るパスが画像処理 アルゴリズムを表わす。検査アルゴリズムはさらに，こ れらのノードにあらかじめ用意した特徵抽出子を組み合 わせることにより表現できる。

\section{3. 検査アルゴリズムの評価值の算出法}

\section{1 画像特徵量と品質の相関モデル ${ }^{9), 10)}$}

検査の最終的な目的は，良品および不良品を判別する ことであるが，実際の製品には品質のばらつきが存在す るため, 良品と不良品とにはっきり分けられないあいま いな中間のクラスタが存在することが多い，不良に近い

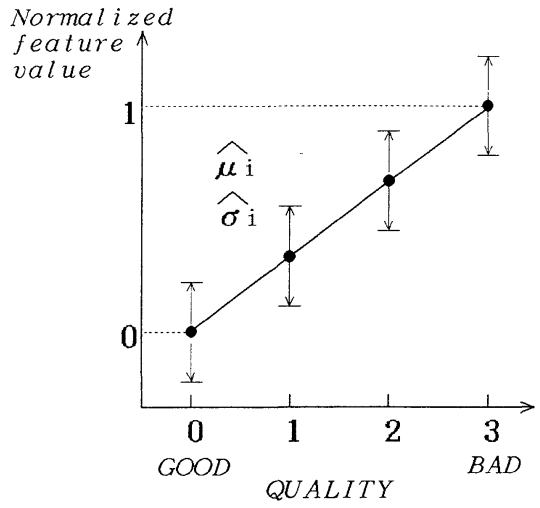

Fig. 4 A correlation model

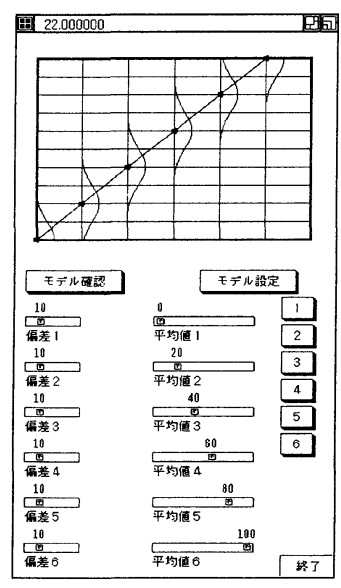

(a) Linear Model

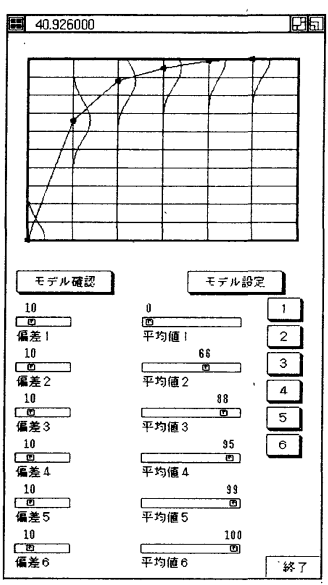

(b) NonLinear Model
Fig. 5 Examples of correlation model

良品，良品に近い不良品というのがこれに当たる．欠陥 検査においては，この中間のクラスタをどう取り扱うか によって歩留まりが左右されるため，検査アルゴリズム を生成する際には，この中間クラスタの取り扱いを検査 者が自由に設定できることが望ましい.

本システムでは，これを可能とするために，相関モデ ルと呼ぶ検查者の意図を入力するインタフェースを用意 した. Fig. 4 に相関モデルを示す.相関モデルは, 良品か ら不良品までの各品質クラス夕の，ある一つの特徵量軸 に関する分布状態を示す。 $i$ 番目の品質クラス夕の分布 は, 特徵量の平均値 $\widehat{\mu}_{i}$ とクラス夕内分散值 $\widehat{\sigma}_{i}$ とで表わ す。これらは，良品クラス夕の平均値を $0 \%$, 不良品ク ラスタの平均值を $100 \%$ として規格化した值である。相 関モデルの入力は Fig. 5 に示すように， $\widehat{\mu}_{i}$ と $\widehat{\sigma}_{i}$ をマウ スを用いて，その形を確認しながら行うことができる. 
たとえば，判定のしきい値を調整することによって不良 率を操作したい場合や, 欠陥の程度を知りたい場合には, Fig. 5 (a) に示すように, 各品質クラスタの検査アルゴ リズムによる出力結果すなわち特徵量が等間隔に分布し ていることが望ましい. また，良品とそれ以外の品質を 明確に判別したいときには，Fig. 5 (b)のような入力を 行えば良い。この入力と同時に, 各品質クラスタの平均 值について，(100- $\left.\widehat{\mu}_{i}\right)$ とするモデルも内部で自動的に 作成する.これは, 検查アルゴリズムの出力結果すなわ ち特徵量が, その特徵量軸上で良品, 不良品に対して増 加傾向を示すものと, 減少傾向を示すものの両方を考慮 するためである。増加傾向を示す相関モデルをモデル 1 , 減少傾向を示すモデルをモデル 2 とする。

試行した検査アルゴリズムの相関モデルによる評価 は，つぎに述べる一致度によって行う。一致度の值 $M$ は, 試行した検査アルゴリズムによる品質クラスタと特 徵量分布の関係がモデルと一致したとき 1 , 一致の度合 が亜くなるほど0に近い值となる，以下に手順を示す。

まず前準備として, 試行検査アルゴリズムによって抽 出された特徵量の各品質グレードにおける平均值 $\mu_{i}$, 分 散值 $\sigma_{i}$ を次式により規格化する。

i ) $\mu_{0}<\mu_{N}$ のとき

$$
\begin{aligned}
& \mu_{i}^{\prime}=\left\{\left(\mu_{i}-\mu_{0}\right) /\left(\mu_{N}-\mu_{0}\right)\right\} \times 100 \\
& \sigma_{i}^{\prime}=\left\{\sigma_{i} /\left(\mu_{N}-\mu_{0}\right)\right\} \times 100
\end{aligned}
$$

ii ) $\mu_{0}>\mu_{N}$ のとき

$$
\begin{aligned}
& \mu_{i}^{\prime}=\left\{\left(\mu_{i}-\mu_{N}\right) /\left(\mu_{0}-\mu_{N}\right)\right\} \times 100 \\
& \sigma_{i}^{\prime}=\left\{\sigma_{i} /\left(\mu_{0}-\mu_{N}\right)\right\} \times 100
\end{aligned}
$$

ここで， $i$ は製品の品質クラスタを表わし $N$ は品質クラ ス夕数で 0 が良品を表わし $N$ が不良品を表わす。

つぎに，一致度関数 $f$ を次式のように定義する。 $f_{1}\left(\widehat{\phi}_{1}, \phi\right)$

$$
=\exp \left[-\sum_{i=0}^{N}\left\{\alpha^{2}\left(\bar{\mu}_{i 1}-\mu_{i}^{\prime}\right)^{2} \times \exp \left\{\left(\sigma_{i}^{\prime}-\bar{\sigma}_{i 1}\right) \beta\right\}\right]\right.
$$

ここで, 1 は相関モデル ID, $\hat{\phi}_{1}=\left(\hat{\mu}_{i 1}, \widehat{\sigma}_{i 1}\right)$ は相関モデ ル, $\phi=\left(\mu_{i}^{\prime}, \sigma_{i}^{\prime}\right)$ は検查アルゴリズムの出力結果を $(1)$ 式 で規格化したもの， $\mu_{i 1}, \sigma_{i 1}$ は相関モデルの各製品グレー ドにおける平均, 分散值, $\alpha, \beta$ は係数をそれぞれ表わす. 上式は，良品と不良品の中間クラスタにおけるモデルと の一致度を示し， $\hat{\mu}_{i 1}$ についての 2 乘誤差の項に $\widehat{\sigma}_{i 1}$ を 基準とした補正項を掛け合わせたものである。この補正 項の值は，試行した検査アルゴリズムの結果，ある品質 クラスタの分散がモデルの分散よりも小さいと小さくな り，逆にモデルの分散よりも大きいと大きくなる。その 結果一致度 $M$ による評価は, 特徵量の分布がモデルと 少々異なっていても，クラス夕内分散が小さければ良く

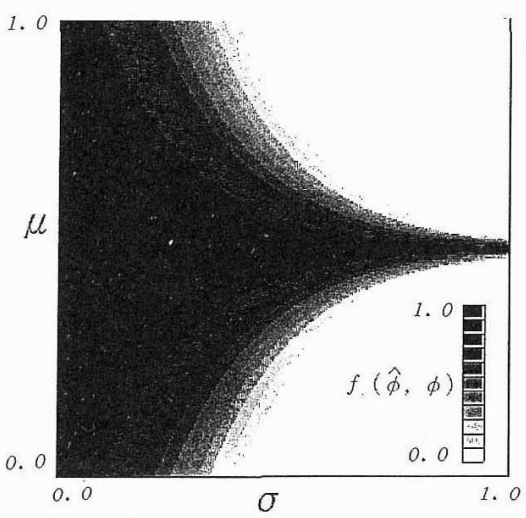

Fig. 6 A distribution of the maching function

なり，クラスタ内分散が大きければ特徵量の分布がモデ ルと似ている場合でも悪くなるという，人間の直感的な 評価に近くなる。係数 $\alpha, \beta$ はそれぞれ相関モデルとの平 均值のずれ，および分散值のずれを一致度 $M$ にどれだ け反映させるかを決めるもので，ここでは実験的に值を 決めた。 $\alpha=5.0, \beta=10.0$ (2) 式において, 品質クラス 夕数を $1, \widehat{\mu}_{0}=0.5, \widehat{\sigma}_{0}=0.5, \alpha=5.0, \beta=10.0$ とし $\mu_{0}^{\prime}$, 首をパラメータとしたときの一致度関数の分布を Fig. 6 に示す。最後に，モデル 1 とモデル 2 の評価のうち，良 いほうを取ることによって一致度 $M$ を求める。

$$
M=\max \left\{f_{1}\left(\hat{\phi}_{1}, \phi\right), f_{2}\left(\hat{\phi}_{2}, \phi\right)\right\}
$$

この一致度 $M$ が検査アルゴリズムの相関モデルを基準 とした評体となる。

\section{2 実現可能性を考慮した良品, 不良品の分離度}

前節では, 各品質クラスタの特徵量軸上での分布状態 に注目した検査アルゴリズムの評価法について述べた。 一般に, 検查装置に要求される機能は

（1）外乱に強く，安定して検査できること.

（2）再現性良く検査できること.

（3）照明，撮像系などの実現が容易であること。

であり，検査アルゴリズムの評価においては，さらにこ れらを考慮する必要がある。

そこで本システムでは, Fig. 7 に示す二つの評価值, 量 子化可能数 $E_{d}$ と分離余裕 $E_{m}$ を定義し, 良品と不良品 との分離度 $S$ をこれらの積で表わした。ここで, 量子化 可能数 $E_{d}$ は良品と不良品クラスタとの平均值間の差を 表わし, 分離余裕 $E_{m}$ は良品と不良品クラス夕とのクラ ス夕内分散を考慮した分離余裕を示す。 $E_{d}$ と $E_{m}$ は, 共 に最小量子化単位, すなわち特徵量の分解能によって正 規化する. 分離度 $S$ は, 值が大きいほど良品および不良 品間の分離性が良く, 光源の変動などの外乱にも強いと 考えられる。また，しきい値決定の際に選択の幅が広く 


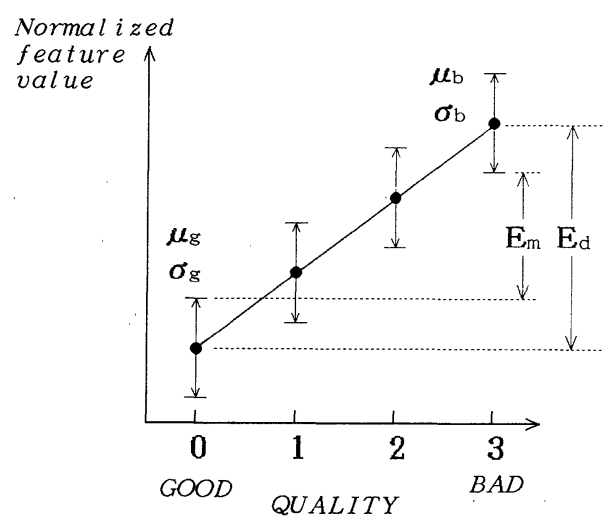

Fig. 7 Quantized number $\left(E_{d}\right)$ and separation margin $\left(E_{m}\right)$

なり，良品率，誤り率といった生産上の品質管理デー夕 の予測, 調整を容易に行うことができる. $S, E_{d}, E_{m}$ はそ れぞれ次式により算出する。

$$
\begin{aligned}
S= & E_{d} \times E_{m} \\
E_{d}= & \left|\mu_{g}-\mu_{b}\right| / q \\
E_{m}= & \exp \left(-\gamma E_{m}^{\prime}\right)+E_{m}^{\prime} \quad\left(E_{m}^{\prime} \geqq 0 \text { のとき }\right) \\
& \exp \left\{(1-\gamma) E_{m}^{\prime}\right\} \quad\left(E_{m}^{\prime}<0 \text { のとき }\right) \\
E_{m}^{\prime}= & \left\{\left(\mu_{b}-\sigma_{b}\right)-\left(\mu_{g}+\sigma_{g}\right)\right\} / q \\
\quad\left(\mu_{b}>=\mu_{g} \text { のとき }\right) & \\
& \left\{\left(\mu_{g}-\sigma_{g}\right)-\left(\mu_{b}+\sigma_{b}\right)\right\} / q \\
& \left(\mu_{b}<\mu_{g} \text { のとき }\right)
\end{aligned}
$$

ここで, $\mu_{g}, \mu_{b}$ は良品, 不良品クラス夕の平均値, $q$ は量 子化係数 (特徵量の最小量子化単位), $\sigma_{g}, \sigma_{b}$ は良品, 不 良品クラス夕の分散值, $\gamma(0<\gamma<1)$ は $E_{m}$ が必ず正の值 を取るように，しかも $E_{m}^{\prime}$ が負の大きな值の場合に 0 に 近付くようにするために導入した係数であり，ここでは $\gamma=0.3$ としている.

\section{3 評価値算出法}

これまでに述べたそれぞれの評価法すなわち，一致度 $M$ と分離度 $S$ から検査アルゴリズムの評価値 $E$ を求め る. 分離度 $S$ が大きいほど検査アルゴリズムはロバスト になり，一致度 $M$ の值が大きいほど検査対象をどのよ うに判別したいかという検查者の意図が反映される。ま た，どちらか一方の評価が良くても，他方の評価が悪け れば，検査アルゴリズムとしての評価を下げるために， 評価值 $E$ は, 次式のように両者の積で表わす。

$$
E=M \times S
$$

\section{4. アルゴリズム木の探索方法 ${ }^{11}$}

2 章で述べた画像処理アルゴリズム木の探索の目標 は, 評価値が最大かつ画像処理コストが最小になるノー ドを探索により発見することである，ここでまず，探索
の指標として各ノードにつぎの属性值を定義する.（1） $E_{n d}$ : 試行によって得られた評価值.（2） $A_{n d}$ : 試行が 終了している下位のノードのうち最大の評価值とノード 自身の評価値のうち大きいほう, 以後効用值と呼ぶ. (3) $I_{n d}$ : ノードで表わされる画像処理モジュール単体の画 像処理コスト(実行時間) (4) $C_{n d}$ : 下位のノードの中 で評価值の一番大きいノードへ至るまでの画像処理コス トの総和, 以後総画像処理コストと呼ぶ. (5) $\Delta A_{n d}$ : 下 位のノードに対して探索を行った際得られた効用值と現 在の効用値の差分.（6） $\Delta C_{n d}$ : 下位ノードに対して探 索を行った際の総画像処理コストと現在の総画像処理コ ストとの差分.（7） $L_{n d}=\Delta A_{n d} / \Delta \dot{C}_{n d}$ ：限界効用値.こ こで, $n d$ はノードの $I D$ を表わし, $d$ は階層番号, $(d+1)$ は一つ下の階層すなわち子ノードを表わす。ノード nd の下位ノードとは，ノード ndよりも階層が下でルート ノードに至るパスにノード nd が存在する, 全てのノー ドのことをいう.ノード ndの上位ノードとは，ノード nd からルートノードに至るパスに存在する全てのノー ドのことをいう. また, 試行とは, 下位ノードにおいて, ルートノードからのパスで表現される画像処理アルゴリ ズムに対して，すべての特徴抽出モジュールを組み合わ せて得られるすべての検査アルゴリズムの評価値 $E$ を 算出し，その中から評価值が最大となる検査アルゴリズ ムをノードの評価值 $E_{n d}$ として選択することである。つ ぎに，アルゴリズム木のあるノードにおける探索の手順 について述べる。

手順 1 : 子ノードの試行が終っていない場合は，すべ ての子ノードについて試行した結果, 評価值 $E_{n(d+1)}$ が 一番高い子ノードを選択し $A_{n d}, C_{n d}, \Delta A_{n d}, \Delta C_{n d}, L_{n d}$ を更新し，上位ノードに伝搬する。

手順 2:子ノードの試行が終ってる場合には, 子ノー ドのうち限界効用值 $L_{n(d+1)_{i}}$ が一番大きなノードについ て手順 1 を繰り返す.

手順 3 : 手順 2 で子ノードの限界効用值がすべて 0 の 場合そのノードについての探索を打ち切る.

本システムでは，以上の手順をルートノードについて 探索打ち切りまで行っている.

ここでの基本的な考え方は，探索ノードの決定におい て総画像処理コストが低く評価值が高くなるようなノー ドを選ぶことであり，この探索法により探索ノード数削 減および探索目標の早期発見が期待できる.

ただし，ノードの各属性値については，以下のような 仮定を設けている.

[仮定 1] 総画像処理コスト対して, 効用值は単調増 加する.

［仮定 2］限界効用值は, 総画像処理コストが小さい 


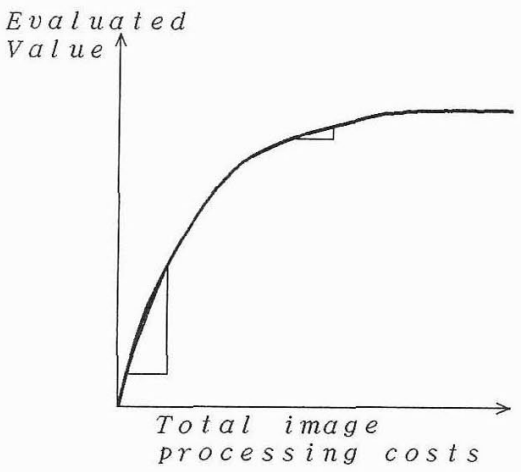

Fig. 8 A relation between an evaluation value and amounts of image processing costs

ほど，值が大きくなる。

[仮定 3] 限界効用值は, 総画像処理コストが大きい ほど，值が小さくなる。

これらの仮定を Fig. 8 に図示する。すなわち,あるノー ドに対してそれ以下のノードの探索を続ける場合，探索 を続ければ必ず効用值は增加する，つまり評価值の高い 検査アルゴリズムが得られるが，その効用值の増加傾向 は探索の初期ほど高く，探索が進むほぼ低くなることを 示している。

\section{5. 実験結果と考察}

ここでは，本システムを用いて検査アルゴリズムを生 成した結果について述べ，その有効性，検查アルゴリズ ムの詊価法および探索法についての考察を行う。蚞査対 象には，電子部品であるコネク夕の成形品を用いた。検 査アルゴリズムの生成システムは，ワークステーション (VaxStation 3520) 上にインプリメントした。また，画 像入力は，パーソナルコンピュータ (PC 9801)で行い, 両者を Ethernet で結ぶことによって画像データをワー クステーションに転送している。本システムで現在使用 している画像処理演算子および特徵抽出子の種類を Table 1 に示すが，これらは，簡単に追加，削除すること ができる。画像処理アルゴリズムのパイプライン段数は, ワークステーションのメモリの制約上 3 段とした。 また，

Table 1 Image processing modules and feature extraction modules

\begin{tabular}{|c|c|}
\hline $\begin{array}{l}\text { Image } \\
\text { processing } \\
\text { modules }\end{array}$ & $\begin{array}{l}\cdot 3 \times 3 \text { differentiations } \\
\text { (8 directions) } \\
\text { - Self-correlation } \\
\text { - Mutual-correlation } \\
\text { - Binarization }\end{array}$ \\
\hline $\begin{array}{l}\text { Feature } \\
\text { extraction } \\
\text { modules }\end{array}$ & $\begin{array}{l}\cdot \text { X-center gravity } \cdot \text { Y-center gravity } \\
\text { - Aspect ratio } \cdot \text { Maximum } \cdot \text { Minimum } \\
\text { - Average } \cdot \text { Median } \cdot \text { Variance } \cdot \text { Area }\end{array}$ \\
\hline
\end{tabular}

画像処理コストは 2 值化を 1 とし，それ以外はマスクの 大きさにより定義した。たとえば自己相関の場合はウィ ンドウサイズを画像処理コストとした。

\section{1 検査アルゴリズムの生成例}

\section{1 .1 生成例 1}

まず，設計者が試行錯詔的に構成した検査アルゴリズ ムと本システムにより自動的に生成された検查アルゴリ ズムを比較することによって本システムの有効性を示 す.Fig.9 に検査サンプルの概略図, およびその欠陥の様 子を示す。また，サンプルの入力画像および検查ウィン ドウを Fig. 10 に示す.この欠陥は, 金型の中に樹脂が十 分充填されないために起こり，ショートショットと呼ば れるもので，コネク夕においてはしばしば問題となる欠

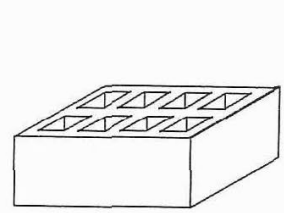

(a) good

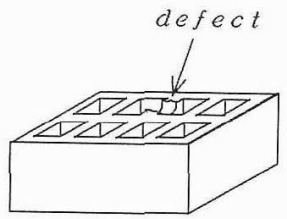

(b) bad
Fig. 9 A rough sketch of inspected products 1

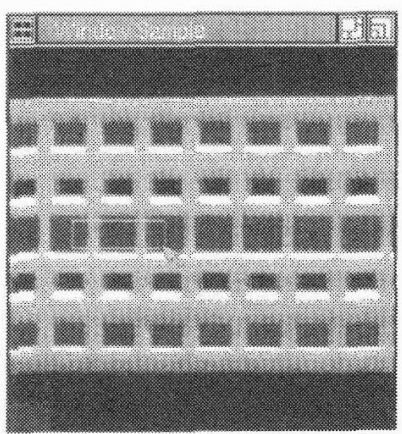

Fig. 10 An example of processing window 1

Table 2 Inspection samples

\begin{tabular}{c|c|l|l|c}
\hline \hline No. & Grade & W $[\mathrm{mm}]$ & $\mathrm{D}[\mathrm{mm}]$ & Number \\
\hline 0 & GOOD & 0 & 0 & 12 \\
1 & $\downarrow$ & 0.05 & 0.05 & 12 \\
2 & $\downarrow$ & 0.1 & 0.1 & 12 \\
3 & BAD & $0.2>=$ & $0.2>=$ & 12 \\
\hline
\end{tabular}

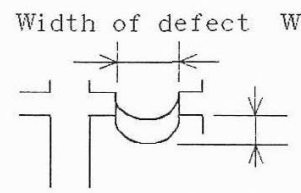

Depth of defect D 


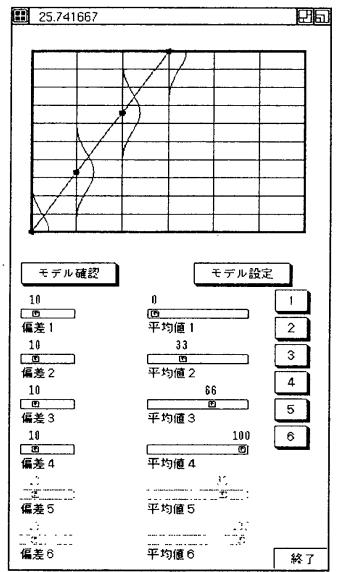

Fig. 11 A correlation model 1_1

Table 3 Results of algorithm generation 1_1 (Sorted by evalutaion value)

\begin{tabular}{c|l|c|c|c|c}
\hline \hline No. & $\begin{array}{l}\text { Image Processing } \\
\text { Algorithm }\end{array}$ & Feat. & Eval. & Cost & Eval./Cost \\
\hline 1 & $\begin{array}{l}\text { Diff.90-> Bin.-> } \\
\text { Self.Corr. }\end{array}$ & Max & 5478 & 138 & 40 \\
\hline 2 & $\begin{array}{l}\text { Diff.270-> Bin.-> } \\
\text { Self.Corr. }\end{array}$ & Min. & 4538 & 138 & 33 \\
\hline 3 & $\begin{array}{l}\text { Diff.90->Bin.-> } \\
\text { Self.Corr. }\end{array}$ & Ave & 4079 & 138 & 30 \\
\hline 4 & $\begin{array}{l}\text { Diff.270-> Bin.-> } \\
\text { Self.Corr. }\end{array}$ & Ave & 3339 & 138 & 24 \\
\hline
\end{tabular}

陥である. 検查サンプルは, Table 2 に示すように不良の 程度によって四つの品質に分け，システムに入力した. また，検査アルゴリズムの評価に用いる相関モデルは，

Fig. 11 に示すものを用いた.

Table 3, Table 4, Fig. 12 にシステムが出力したアル ゴリズム生成の結果を示す. Table 3 は，3 章の評価值 によって順位付けを行った検査アルゴリズムの候補であ り, Table 4 は評価值/総画像処理コスト比によって順位 付けを行った結果である。また，Fig. 12 は，Table 3 の それぞれの候補についての各品質クラス夕の特徵量軸上 での分布を示している. 同図で, 横軸は製品の品質を表 わし， 0 が良品，数が大きくなるほど大きな不良である ことを示す。また，縦軸は抽出された特徵量を表わし， 図の左側に検查アルゴリズムにより抽出された值の最大 值, 最小值を, 図の右側には特徵量自体の值の範囲を示 している.

この結果から検査アルゴリズムを選ぶ際, 良品と不良 品の分離特性のみに注目するのであれば評価值を基準と して検査アルゴリズムの選択を行えば良く, 検査時間が 問題になるのであれば評価値/コスト比を基準として選
Table 4 Results of algorithm generation 1_1 (Sorted by evaluation value/cost)

\begin{tabular}{c|l|c|r|c|c}
\hline \hline No. & $\begin{array}{l}\text { Image Processing } \\
\text { Algorithm }\end{array}$ & Feat. & Eval. & Cost & Eval./Cost \\
\hline 1 & Diff.90-> Bin. & Area & 2713 & 10 & 271 \\
\hline 2 & Diff.270-> Bin. & Area & 2302 & 10 & 230 \\
\hline 3 & Diff.135 & Max & 735 & 9 & 82 \\
\hline 4 & Diff.315 & Ave & 683 & 9 & 76 \\
\hline
\end{tabular}
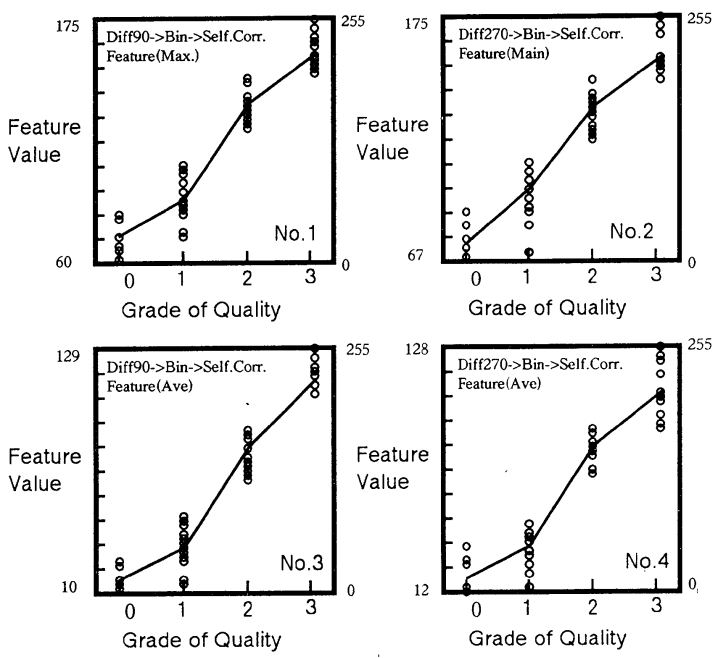

Fig. 12 Results of algorithm generation 1_1

択を行えば良い。いずれにしても，目的に応じて，検査 者はこれらの結果の中から検査アルゴリズムを自由に選 択することができる。

このコネクタに対する検査装置を開発するにあたつて 本システムの開発以前に，欠陥の形状特徵とそのときの 画像上の明暗パターンについて詳細な検討を行い,さら に，検査時間，安定性および再現性を考慮して検査アル ゴリズムの決定を行った。この結果得られた検査アルゴ リズムは, Table 4 の 1，2 位と全く同じであった.この ことから，本システムにより生成される検査アルゴリズ ムは，実際の検査において有効であるといえる.

\section{1 .2 生成例 2}

つぎに，同じ製品について相関モデルを変更して検査 アルゴリズムの生成を行った例を示す. Fig. 13 に相関モ デルを示す。これは，良品とそれ以外の品質を明確に分 離することを意図したものである。結果を Table 5,

Table 6, およびFig. 14 に Table 5 の結果を示す. Table 5 は, 評価值順の生成結果であり, Table 6 は, 評価値/ 総画像処理コスト比順の生成結果である。また Fig. 14 は, Table 5 の結果をグラフ表示したものである. 


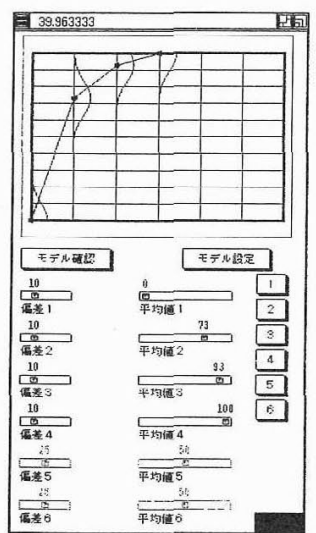

Fig. 13 A correlation model 1_2

Table 5 Results of algorithm generation 1_2 (Sorted by evaluation value)

\begin{tabular}{c|l|c|c|c|c}
\hline \hline No. & $\begin{array}{l}\text { Image Processing } \\
\text { Algorithm }\end{array}$ & Feat. & Eval. & Cost & Eval./Cost \\
\hline 1 & Diff.315->Diff.180 & Max & 6.4 & 18 & 0.356 \\
\hline 2 & Diff.135 > Diff.180 & Med & 2.7 & 18 & 0.15 \\
\hline 3 & Diff.315->Diff.180 & Med & 1.5 & 18 & 0.08 \\
\hline 4 & $\begin{array}{l}\text { Diff.90-> Bin.-> } \\
\text { Self.Corr. }\end{array}$ & Max & 1.3 & 238 & 0.01 \\
\hline
\end{tabular}

Table 6 Results of algorithm generation 12 (Sorted by evaluation value/cost)

\begin{tabular}{c|l|c|c|c|c}
\hline \hline No. & $\begin{array}{l}\text { Image Processing } \\
\text { Algorithm }\end{array}$ & Feat. & Eval. & Cost & Eval./Cost \\
\hline 1 & Diff.315->Diff.180 & Max & 6.4 & 18 & 0.356 \\
\hline 2 & Diff.135->Diff.180 & Med & 2.7 & 18 & 0.15 \\
\hline 3 & Diff.315->Diff.180 & Med & 1.5 & 18 & 0.08 \\
\hline 4 & Diff.135 & Max & 0.3 & 9 & 0.03 \\
\hline
\end{tabular}
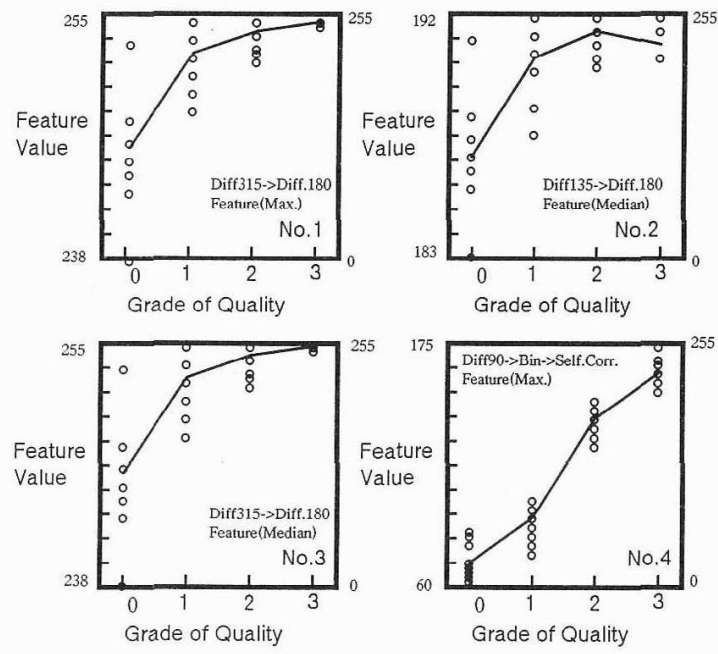

Fig. 14 Results of algorithm generation 1_2

\section{1.3 生成例 3}

最後に, 別のコネクタに対して生成を行った例を示す。 Fig. 15 にサンプルの概略図および欠陷の様子を示し, サ ンプルの入力画像执よび検査ウィンドウを Fig. 16 に示 す。またサンプルは，良品，不良品および中間の三つの 品質に分類し，それぞれ 10 個のサンプルを用いた。中間 の品質は, Fig. 15 に示す不良部がルーペで見える程度の もので，不良品はそれが肉眼で見えるものとして分類し た。このとき用いた相関モデルを Fig. 17 に示す。このと きの結果を, Table 7, Table 8, および Fig. 18 に Table 7 の結果示す。

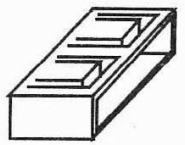

(a) good

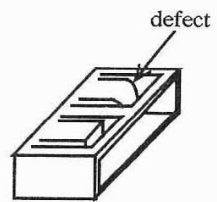

(b) bad
Fig. 15 A rough sketch of inspected products 2

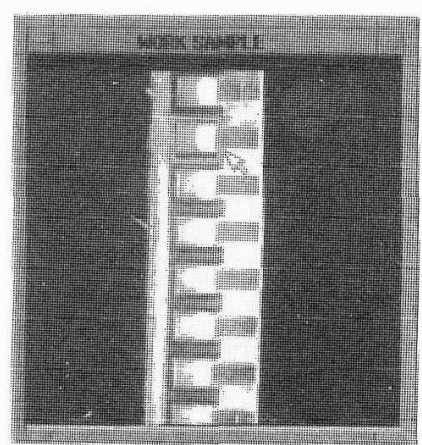

Fig. 16 An example image of Sample 2

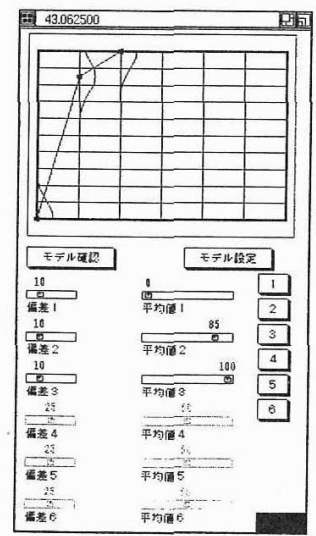

Fig. 17 A correlation mode 2 
Table 7 Results of algorithm generation 2 (Sorted by evaluation value)

\begin{tabular}{c|l|c|c|c|c}
\hline \hline No. & $\begin{array}{l}\text { Image Processing } \\
\text { Algorithm }\end{array}$ & Feat. & Eval. & Cost & Eval./Cost \\
\hline 1 & $\begin{array}{l}\text { Diff.270-> Bin-> } \\
\text { Self Corr }\end{array}$ & Min & 2994.4 & 330 & 9.1 \\
\hline 2 & Diff:135->Diff.45 & Max & 2785.6 & 18 & 154.8 \\
\hline 3 & Diff.315->Diff.45 & Max & 2768.4 & 18 & 153.8 \\
\hline 4 & Diff.135->Diff.225 & Max & 2757.2 & 18 & 153.2 \\
\hline
\end{tabular}

Table 8 Results of algorithm generation 2 (Sorted by evaluation value/cost)

\begin{tabular}{c|l|c|c|c|c}
\hline \hline No. & $\begin{array}{l}\text { Image Processing } \\
\text { Algorithm }\end{array}$ & Feat. & Eval. & Cost & Eval./Cost \\
\hline 1 & Diff.135-> Diff.45 & Max & 2785.6 & 18 & 154.8 \\
\hline 2 & Diff.315-> Diff.45 & Max & 2768.4 & 18 & 153.8 \\
\hline 3 & Diff.135-> Diff.225 & Max & 2757.2 & 18 & 153.2 \\
\hline 4 & Diff.315-> Diff.225 & Max & 2754.2 & 18 & 153.0 \\
\hline
\end{tabular}
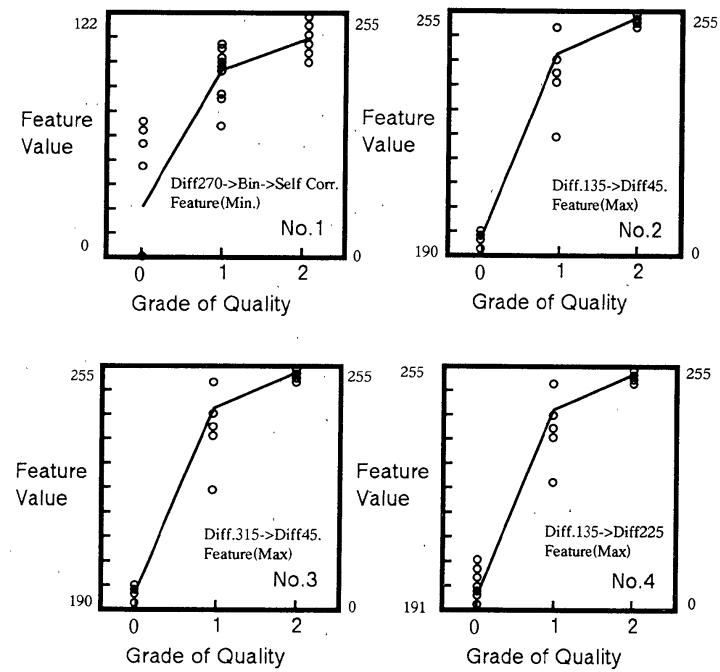

Fig. 18 Results of algorithm generation 2

\section{1 .4 検査アルゴリズム評価法の評価}

以上の結果から，今回提案する検査アルゴリズムの評 価法についての考察を行う. Fig. 12, Fig. 14, Fig. 18 よ り，得られたすべての検査アルゴリズムは；相関モデル を用いて意図したとおり，各製品クラスタが特徴量軸上 に分布したものであることがわかる。また Fig. 12 では， 製品クラスタ０と３は十分離れており，その分布に重な りもない.さらに Fig. 14 では, 相関モデル形状とはあま り一致していないが，各品質クラスタ間の分離の良い検 査アルゴリズムが選択されている，これらのことから， 本論文で提案する評価法は有効であるといえる。
Table 9 Evaluation of tree search method

\begin{tabular}{r|c|c|c}
\hline \hline No. & $\begin{array}{r}\text { Search time } \\
{[\mathrm{min}]}\end{array}$ & $\begin{array}{c}\text { Searched } \\
\text { rate [\%] }\end{array}$ & $\begin{array}{c}\text { Total number } \\
\text { of } \\
\text { searched node }\end{array}$ \\
\hline 1 & 5 & 15 & 18 \\
2 & 10 & 37 & 46 \\
3 & 15 & 69 & 68 \\
4 & 20 & 69 & 90 \\
5 & 25 & 85 & 114 \\
6 & 30 & 99 & 132 \\
7 & 35 & 99 & 160 \\
8 & 40 & 99 & 172 \\
9 & 45 & 99 & 202 \\
10 & 50 & 99 & 220 \\
11 & 55 & 100 & 244 \\
12 & 60 & 100 & 262 \\
\hline
\end{tabular}

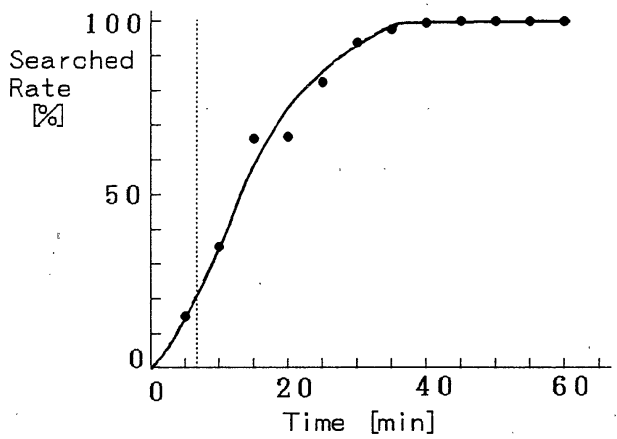

Fig. 19 Time and searched rate

\section{2 探索法の評価}

ここでは, 提案した探索法の評価を行う. 評価の方法 は, システムが探索を打ち切った時点で発見された検査 アルゴリズムの上位 20 位を基準として, それまでの経過 時間を等間隔に区切り，それぞれの時点での探索状態を 次式に示す発見率 $F$ により評価した。 なお，検査サンプ ルには，前節と同じものを用いている。

$$
F=\frac{S}{S_{r}} \times 100[\%]
$$

ここで, $S_{r}$ は探索終了時の候補アルゴリズム 1～20 位に 対し，1位に 21 点，2位に 20 点のように順にスコアを つけたときのスコアの総計を表わし， $S$ は各探索時点で の候補の中で最終順位に現れているもののスコアの総計 を表わす.生成例 1 に対する結果を, Table 9 および Fig. 19 に示す. 発見率は, 探索の初期において増加し, それ 以降ではその増加の傾向が鈍くなっているのがわかる. このことは, 探索の初期において探索終了時の候補の大 半が発見されていることを示す. 同図に示している破線 は，探索打ち切り時での 1 位の候補が, この時点で発見 されたことを示している.さらに Table 9 より, 探索終 
了時点で探索が行われたノードの総数は全体のノード数 の $10 \%$ 程度であり，探索が効率良く行われたことを示し ている．以上のことから，今回提案した探索方法の有効 性が示された。

\section{6. 結 論}

画像処理を用いた検査システムを構築する際に問題と なる汎用化を支援するため，製品画像の例示による検査 アルゴリズムの生成システムを開発した。ポイントを以 下に列挙する。

（1）画像処理に対して特別な知識をもたない現場の 生産技術者が，製品サンプルのグレード分けや画像の入 力などの簡単な入力操作を行うだけで検査アルゴリズム を生成する，支援システムを構成した。

（2）試行検査アルゴリズムの総合評価值 $E$ を, 良品 と不良品をどのように判別したいかという検査者の意図 を評価する一致度 $M$ と, 検査の安定性, 再現性, 実現性 を評価する良品と不良品の分離度 $S$ の積から求める方 式を提案し，その有効性を実際の成形品検査において確 認した。

（3）木構造で表現した画像処理アルゴリズムの組合 せの探索を効率良く行うため, 総合評価值 $E$ と画像処理 コストから限界効用值を求めこれに基づく探索法を提案 した。本探索法が探索時間および探索ノード数の削減に 有効であることを確認した。

現在，パーツフィーダ，検査ワークのハンドリング系 を含めた汎用検査システムを制作中である、今後，本シ ステムで得られた結果をこの検查システム上で検証して いく予定である。また，現状のコネクタでは，1次元の 特徵量の上でも十分良否の判別が可能なものが多いが, ハーフピッチコネクタのように精密な成形を要求される ものでは，安定した成形条件を出すことがをずかしく， 生産中に発生する欠陥の種類も複数になることが考えら れる、今後は，このような製品にどう対応していくかが 課題となり，その際には特徵量の多次元化や部分問題へ

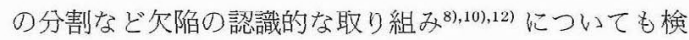
討を加えていく必要がある。

\section{参 考 文 献}

1）渡辺祐司：グレースケールジャッジメントシステム,映像 情報, 22-7，39/44（1990）

2）折田, 長谷川, 鳥脇, 金崎, 高藤 : 会話型評価と自動評価 による画像処理手順のプロダクションシステム, 情報処理 学会論文誌，29-2，105/113（1988）

3）高須, 長谷川, 鳥脇：サンプル図形提示方式による面図形 抽出手順の自動構成法について, 情報処理学会論文誌, 29 $-2,134 / 141$ (1988)

4）谷崎, 岡村, 村上：局所パターンとの相関によるプラスチ ック部品の欠楩娭出, 情報処理学会第 40 回全国大会予稿 集, 4P-5 (1990)

5）谷崎直昭：アルゴリズム木の探索による画像処理アルゴ リズムの生成システム, 第 30 回 SICE 学術講演会予稿集, JS-23-2 (1991)

6）今富芳幸：成形品 (コネクター) の外観検査システム，プ ラスチック成形技術，8-5，14/18（1991）

7) 鳥脇純一郎：画像理解のためのディジタル画像処理 (I), 昭晃堂 (1988)

8) T. Matsuyama : Expert Systems for Image Processing, Computer Vision, Graphics and Inage Processing, 48, 22/49 (1989)

9) 舟久保登：視覚パターンの処理と認識, 啓学出版 (1990)

10) R.C. Vogt: Automatic Generation of Morphological Set Recognition Algorithms, Springer-Verlag (1989)

11）多田和夫：探索理論，日科技連（1980）

12) Y. Kitamura, H. Sato and H. Tamura: An Expert System for Industrial Machine Vision, Proc. of 10th International Conf. on Pattern Recognition, 771/774 (1990)

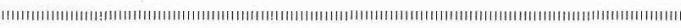
[著 者紹介]

谷 崎 直 昭 (正会員)

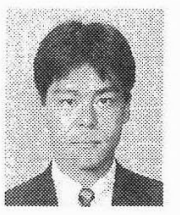

1986 年, 徳島大学大学院工学研究科修士 課程 (電気工学専攻) 修了. 同年住友重機 械工業(株)に入社，現在に至る．以来シス テム技術研究所にて,計算機制御システム, 画像処理検査システム，ヒューマンインタ フェースの研究に従事. 情報処理学会, 日 本医用画像工学会などの会員

岡 村 哲 也 (正会員)

(Vol. 28, No. 8 參照)

村上亨 (正会員)

(Vol. 28, No. 8 参照) 